\title{
Food web diagnostics and functional diversity of soil inhabiting nematodes in a natural woodland
}

\author{
V. V. S. TOMAR, W. AHMAD* \\ Nematode Biodiversity Research Laboratory, Department of Zoology, Aligarh Muslim University, \\ Aligarh-202002 INDIA, *E-mail: ahmadwasim57@yahoo.co.in
}

\begin{abstract}
Summary
Functional diversity and detritus soil food web of soil inhabiting nematodes in natural woodland dominated by Acacia nilotica L. was studied. Functional diversity was studied in terms of trophic groups assessed by Trophic diversity index (TDI) and Shannon-Weaver index (H'), while food web was diagnosed by channel index (CI). The plant parasitic channel was determined by plant parasitic index (PPI). The stability of the soil ecosystem was measured in terms of maturity index (MI), structure index (SI) and enrichment index (EI). Shannon-Weaver index of the area was recorded as $2.1 \pm 0.3$ while trophic diversity index $2.6 \pm 0.7$, maturity index (MI) $3.1 \pm 0.2$, channel index $62.4 \pm 28.1$ and structure and enrichment indices $68.1 \pm$ 18.5 and $15.4 \pm 13.7$ respectively. A high degree of positive correlation was recorded between population of dorylaims and MI while some degree of negative correlation existed between population of plant parasitic nematodes and MI. Population of other nematodes showed a positive correlation with SI and EI. The faunal profile was found to be tilted towards quadrat $\mathrm{C}$ giving the idea of relatively undisturbed ecosystem with moderate enrichment and fungal decomposition channel.
\end{abstract}

Keywords: Channel index; enrichment index; food web diagnostics; functional diversity; India; maturity index

\section{Introduction}

Soil nematodes offer great potential for use as indicator of biodiversity and ecological stability, and for assessing the impact of changing land use on soil condition. The assemblage of plant and soil nematode species occurring in a natural or managed ecosystem constitute nematode community. Their role in a soil ecosystem is to recycle nutrients by feeding plant tissue and micro-organisms and liberating minerals for easy absorption by plant roots. Because of varied life spans and different reproductive and survival capacity, the nematode communities have been used as ecological bio-indicators to reflect environmental changes (Freckman, 1982; Samoiloff, 1987; Bongers, 1990). The abundance of each species in the community can be transformed into ecological indices and parameters to measure community changes in diversity and trophic structure (Bongers, 1990), and further to assess soil disturbance levels and decomposition pathways. Nematode communities can be studied on the basis of functional groups which can be regarded as groups of species that have similar effects like predation or herbivory on ecosystem processes. Ecological indices based on the proportional contribution of each nominal nematode taxon, such as Shannon-Weaver Index $\left(\mathrm{H}^{\prime}\right)$ Trophic diversity index (TDI), Maturity index (MI) and plant parasitic index (PPI) provide focused tools for assessing the stability / disturbance in the ecosystem. The cp (colonizer-persister) values (Bongers, 1990) of species reflect the perceived position on a r-k spectrum based on their reproductive rate and correlated characteristics. The ratio between abundance of two functional groups, i.e., bacteriovores and fungivores, gives an index of the relative contribution of the two main decomposition channels. It is expressed as the Nematode Channel Ratio (NCR). Various functional guilds of nematodes have been described to compute Enrichment index (EI) and Structure index (SI) (Ferris et al., 2001). The enrichment index is based on the expected responsiveness of the opportunistic guilds to the food resourse enrichment. Thus, EI describes whether a soil ecosystem is nutrient enriched (high EI) or depleted (low EI). The SI represents an aggregation of functional guilds with $\mathrm{cp}$ values ranging from 3 to 5. SI describes whether a soil ecosystem is structured/matured (high SI) or disturbed/degraded (low SI).

Although a little is known about the abundance of plant and soil nematodes in tropical forests, some studies suggest that the total nematode population at a given site in a tropical forest may range from 8,100 per $\mathrm{m}^{2}$ to $1,900,000$ per 
$\mathrm{m}^{2}$ (Petersen, 1982). Pradhan and Das (1987) recorded monthly mean nematode populations between 151,000 and $661,000 / \mathrm{m}^{2}$ for Indian forest dominated by Shorea robusta Gaert, F. Other forest soils include 79 species for a Danish forest (Yeates, 1972), 92 species for Slovakian forest (Š́ly, 1975), and 106 species in South West Germany (Ruess, 1995). Ruess (2003) compared decomposition pathways of different ecosystems. He recorded values of channel index (CI) in crop field, grassland and forest as 18 , 24 and 50 respectively. Due to limited knowledge on the nematode community structure of tropical forests in India, the present study was planned. Thus, the objective of the present study was to assess the nematode community dynamics in an undisturbed forest ecosystem

\section{Materials and methods}

The site (27 $43^{\prime} 0^{\prime \prime}$ North, $78^{\circ} 5^{\prime} 0^{\prime \prime}$ East) was an Acacia forest located $15 \mathrm{~km}$ from Aligarh city on Aligarh-Agra highway, Uttar Pradesh, India. It is a natural woodland of Acacia trees covering an area of about 35 ha. Leaf litter covers the upper layer of the soil which is responsible for $\mathrm{pH} 7.2$ of the soil. Available organic carbon of the area was $0.30 \%$, while available potash and available phosphates $20 \mathrm{~g} / \mathrm{m}^{2}$ and $1.7 \mathrm{~g} / \mathrm{m}^{2}$ respectively. This forest is generally free from human interference, as tree cutting is permitted only in the outer area. Bosephalus tragocamelus L. (Blue bull) is mainly responsible for grazing in this forest area. Five sampling sites, each covering an area of 5 $\mathrm{m}^{2}$ were selected randomly. From each site five cores were collected from a depth of $0-10 \mathrm{~cm}$ using a steel corer of 5 $\mathrm{cm}$ diameter, bulked and mixed to form a single sample. Sampling was done in the months of September 2005, December 2005 and March 2006. Samples were brought to laboratory and further processing was followed according to the method of Tomar et al. (2006). Mass slides containing two hundred nematodes per sample were prepared for identification. Identification up to generic level was done mainly using Goodey (1963); Jairajpuri and Khan (1982); Andrássy (1984), Siddiqi (1986), Jairajpuri and Ahmad (1992); Ahmad (1996). Trophic group were allocated according to Yeates et al. (1993) and coloniserpersistor (cp) scale was assigned after Bongers (1990).

Nematode diversity was described using the univariate measures of the Shannon-Weaver index calculated at genus level (H'). Nematodes were assigned to five main trophic groups (bacteriovores, fungivores, herbivores, omnivores and predators) after Yeates et al. (1993). Maturity index was calculated to estimate the relative state of the ecosystem studied ( $M I=\sum V_{i} f_{i}$ ) (where $V_{\mathrm{i}}$ is assigned cp value
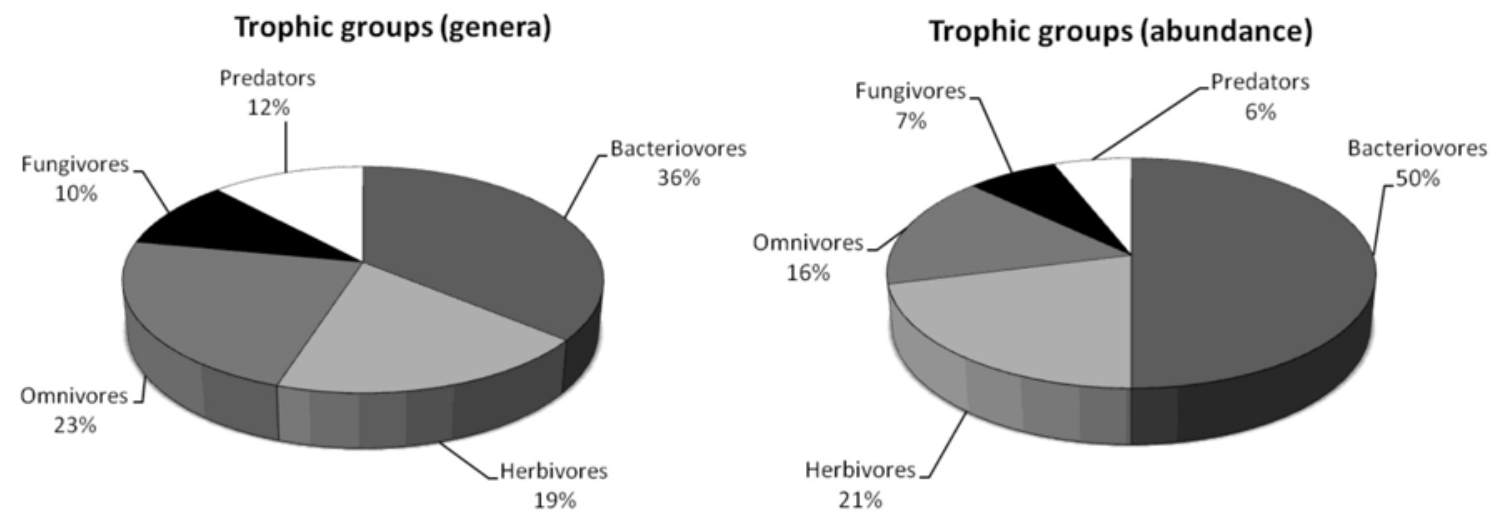

Ordinal diversity (abundance)
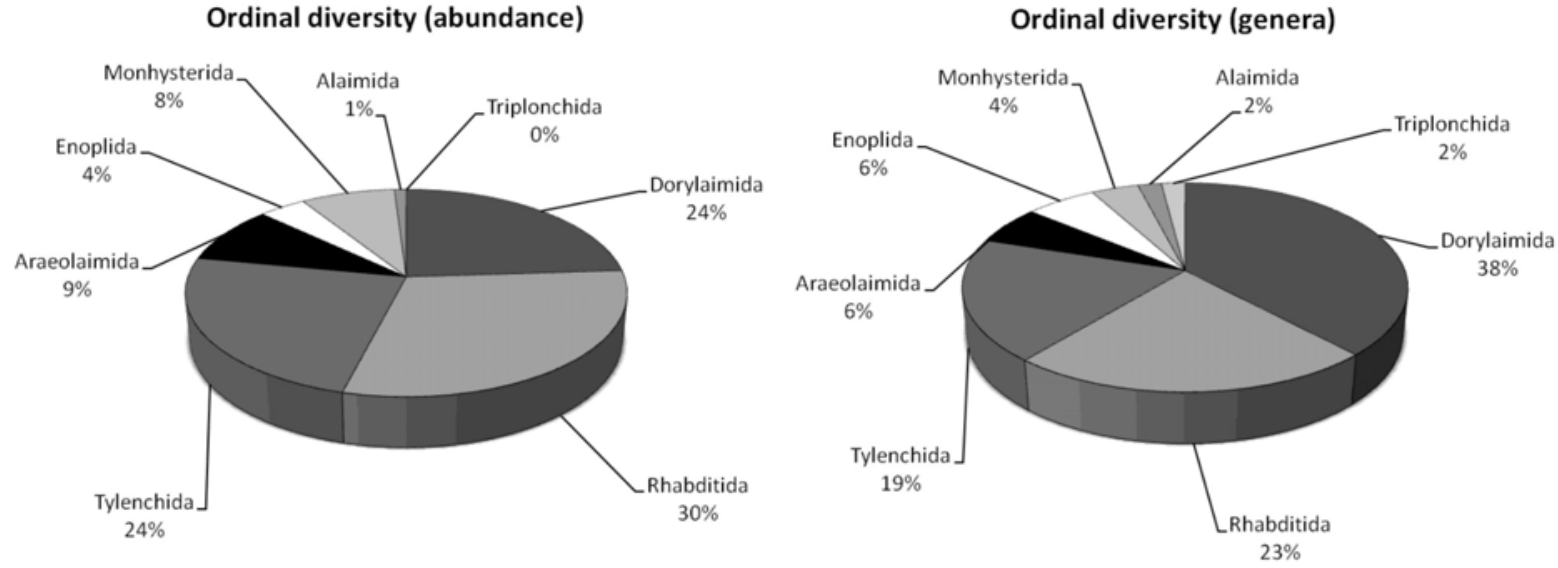

Fig. 1 Community structure of soil inhabiting nematodes in acacia forest 
to taxon $i, f_{\mathrm{i}}$ is frequency of that taxon). Trophic diversity was calculated by the trophic diversity index $(T D I=1 /$ $\sum p i^{2}$ ) (Heip et al., 1988) (where $\mathrm{P}_{\mathrm{i}}$ is proportion of individual of taxon $i^{\text {th }}$ in the total population). The channel index $\left(C I=100 \times 0.8 \mathrm{Fu}_{2} /\left(3.2 \mathrm{Ba}_{2}+F u_{2}\right)\right)$ (Ferris et al., 2001) (where $\mathrm{Fu}_{2}, \mathrm{Ba}_{2}$ are assigned functional guilds) was calculated to indicate predominant decomposition pathways (Ruess, 2003). Structure index $(S I=(s / s+b) x 100)$ and enrichment index $(E I=(e / e+b) x 100)$ (where $\mathrm{e}, \mathrm{b}$ and $\mathrm{s}$ are sum products of assigned weights and number of individuals of all genera) were calculated to determine the relative stability of the ecosystem. In all the above-mentioned indices, nematode families were allocated cp scale according to their perceived life history strategy. All the data were subjected to analysis of variance (ANOVA) in SPSS software program. Differences with $\mathrm{P}<0.05$ were con- sidered significant while those with $\mathrm{P}<0.01$ were highly significant. Correlation between indices and trophic groups were done by SPSS.

\section{Results}

Diversity and abundance (Fig. 1)

A total of fifty two nematode genera belonging to eight orders and twenty four families were recorded. The number of genera in fifteen samples varied from 7 to 16 per sample while abundance varied from 381 to 1404 individuals per $100 \mathrm{~g}$ dry soil. In terms of number of genera, the order Dorylaimida was most frequent followed by Rhabditida, Tylenchida, Enoplida, Araeolaimida, Monhysterida, Alaimida and Triplonchida. In terms of number of individuals, Rhabditida was most abundant, followed by

Table 1. Percent share of nematode genera present in Acacia forest

\begin{tabular}{|c|c|c|c|c|c|c|c|}
\hline Genera & Family & $\begin{array}{l}\text { c-p Value } \\
\text { assigned }\end{array}$ & $\begin{array}{c}\text { Natural } \\
\text { Forest } \\
\%\end{array}$ & Genera & Family & $\begin{array}{l}\text { c-p Value } \\
\text { assigned }\end{array}$ & $\begin{array}{c}\text { Natural } \\
\text { Forest } \\
\%\end{array}$ \\
\hline Acrobeles & Cephalobidae & 2 & 13.6, E & Xiphinema & Xiphinematidae & 5 & $\mathbf{0 . 8 7}, \mathbf{R}$ \\
\hline Acrobeloides & Cephalobidae & 2 & $0.41, \mathrm{R}$ & Fungivores & & & \\
\hline Chiloplacus & Cephalobidae & 2 & $0.47, \mathrm{R}$ & Aphelenchoides & Aphelenchidae & 2 & $1.10, \mathrm{~S}$ \\
\hline Chronogaster & Plectidae & 2 & 7.5, D & Axonchium & Belondiridae & 5 & $0.20, \mathrm{R}$ \\
\hline Cephalobus & Cephalobidae & 2 & $3.68, \mathrm{~S}$ & Dorylaimellus & Belondiridae & 5 & $0.60, \mathrm{R}$ \\
\hline Monhystera & Monhysteridae & 1 & $1.5, \mathrm{~S}$ & Dorylaimus & Dorylaimidae & 4 & $1.21, \mathrm{~S}$ \\
\hline Prismatolaimus & Monhysteridae & 1 & 6.7, D & Dorylaimoides & Mydonomidae & 4 & $3.62, \mathrm{~S}$ \\
\hline Plectus & Plectidae & 2 & $0.75, \mathrm{R}$ & Eudorylaimus & Qudsianematidae & 5 & $2.0, S$ \\
\hline Panagrolaimus & Panagrolaimidae & 1 & $1.22, \mathrm{~S}$ & Ecumenicus & Qudsianematidae & 4 & $0.54, \mathrm{R}$ \\
\hline Rhabditis & Rhabditidae & 1 & $0.82, \mathrm{R}$ & Kochinema & Nordiidae & 4 & $0.27, \mathrm{R}$ \\
\hline Rhabdolaimus & Rhabditidae & 1 & $0.20, \mathrm{R}$ & Labronema & Qudsianematidae & 4 & $0.13, \mathrm{R}$ \\
\hline Tobrilus & Tripylidae & 2 & $0.89, \mathrm{R}$ & Oriverutus & Nordiidae & 4 & $1.76, \mathrm{~S}$ \\
\hline Teratorhabditis & Rhabditidae & 1 & $0.12, \mathrm{R}$ & Poronemella & Qudsianematidae & 4 & 0.13, R \\
\hline Hoplolaimus & Hoplolaimidae & 3 & $1.23, \mathrm{~S}$ & Discolaimus & Qudsianematidae & 5 & $1.90, \mathrm{~S}$ \\
\hline Helicotylenchus & Hoplolaimidae & 3 & $0.46, \mathrm{R}$ & Discolaimoides & Qudsianematidae & 5 & $0.48, \mathrm{R}$ \\
\hline Hemicriconemoides & Criconematidae & 3 & $0.06, \mathrm{R}$ & Ironus & Ironidae & 4 & $1.32, \mathrm{~S}$ \\
\hline Merlinius & Belonolaimidae & 4 & $1.70, \mathrm{~S}$ & Laimydorus & Dorylaimidae & 5 & $0.74, \mathrm{R}$ \\
\hline Tylenchorynchus & Belonolaimidae & 3 & $0.57, \mathbf{R}$ & Triypla & Tripylidae & 3 & $2.05, \mathrm{~S}$ \\
\hline Trichodorus & Trichodoridae & 4 & $\mathbf{0 . 2 7}, \mathbf{R}$ & & & & \\
\hline
\end{tabular}


Table 2. Trophic groups of soil inhabiting nematodes in Acacia forest $(\mathrm{n}=15$, mean \pm SD $)$

\begin{tabular}{lcc}
\hline Trophic Groups & mean \pm SD & Range \\
\hline Bacteriovores & $418 \pm 151.21$ & $216-706$ \\
Herbivores & $210 \pm 94.22$ & $0-348$ \\
Fungivores & $69.38 \pm 56.00$ & $0-233$ \\
Omnivores & $121.07 \pm 85.11$ & $15-291$ \\
Predators & $57.92 \pm 30.9$ & $0-125$ \\
TDI & $2.60 \pm 0.75$ & $1.01-3.46$ \\
\hline
\end{tabular}

Dorylaimida, Tylenchida, Araeolaimida, Monhysterida, Enoplida, Alaimida and Triplonchida. The abundance of dorylaims per sample ranged from $20-53.8 \%$, tylenchids ranged from $0-46.7 \%$, while that of other nematode groups combined together ranged from $23-57 \%$.

Trophic groups (Fig. 1, Tables 1 and 2)

Bacteriovores constituted the most dominant group in terms of number of genera and individuals, followed by herbivores, omnivores, fungivores and predators. The number of bacteriovores in 15 samples ranged from 216 $706(418 \pm 151.2)$ per $100 \mathrm{~g}$ dry soil, followed by herbivores $0-348(210 \pm 94.22)$, fungivores $0-233(69.38 \pm$ $56.0)$, and omnivores $15-291$ (121.07 \pm 85.11$)$. The predators were least abundant, $0-125(57.9 \pm 30.9)$. The trophic diversity index (TDI) of the area ranged from $1.0-$
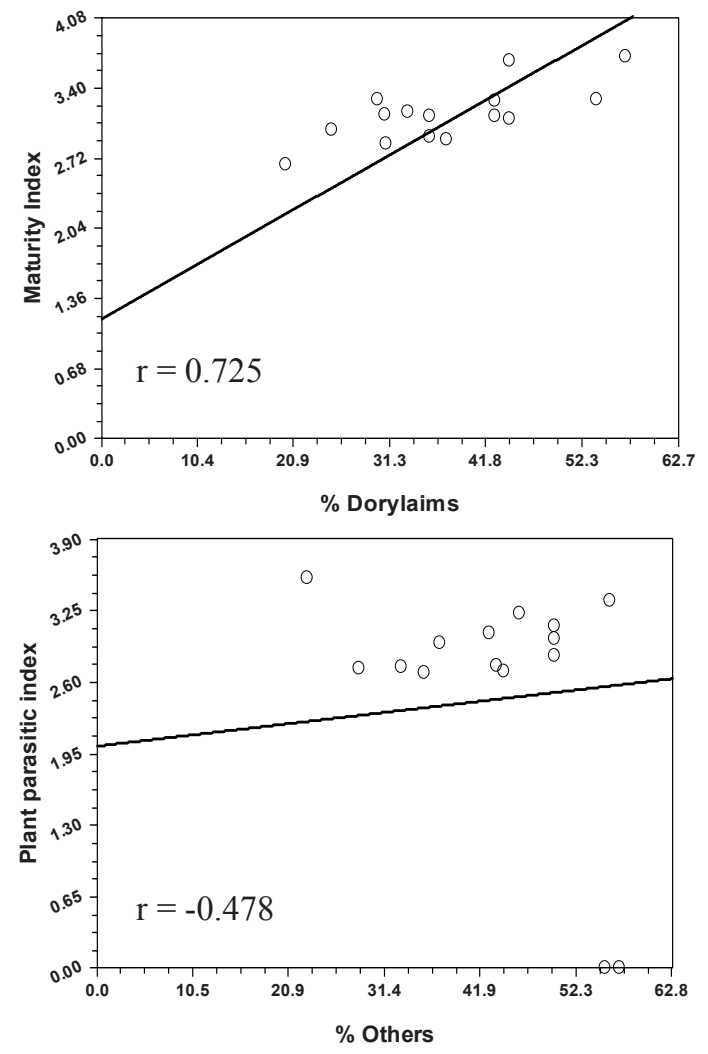

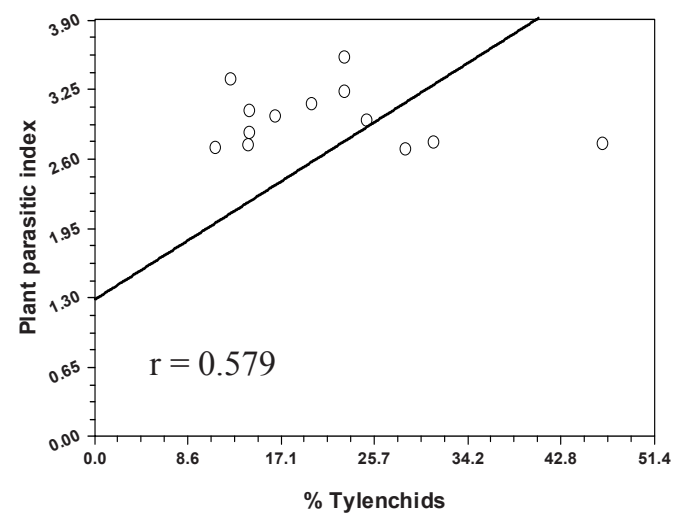

Table 3. Characteristics of Acacia forest $\left(\mathrm{AF}^{*}, \mathrm{n}=15\right.$, mean $\left.\pm \mathrm{SD}\right)$

\begin{tabular}{lcc}
\hline Characteristics & mean \pm SD & Range \\
\hline Number of & $12.33 \pm 3.07$ & $7-16$ \\
nematode Genera & & \\
Abundance & $828.27 \pm 257.02$ & $381-1404$ \\
H' & $2.18 \pm 0.31$ & $1.39-2.57$ \\
MI & $3.16 \pm 0.27$ & $2.67-3.67$ \\
PPI & $3.06 \pm 0.37$ & $0-3.55$ \\
CI & $62.49 \pm 28.13$ & $0-100$ \\
EI & $15.45 \pm 13.73$ & $0-49.92$ \\
SI & $68.15 \pm 18.5$ & $27.13-100$ \\
\hline
\end{tabular}

$3.4(2.6 \pm 0.7)$. Among bacteriovores the genus Acrobeles was most dominant while the genera Boleodorus, Mesodorylaimus, Aphelenchus and Aporcelaimellus were the most dominant among herbivores, omnivores, fungivores and predators, respectively. Least dominant genera among bacteriovores, herbivores, omnivores, fungivores and predators were Teratorhabditis, Hemicriconemoides, Thornenema, Axonchium and Laimydorus, respectively. All the samples contained bacteriovores and omnivores while herbivores, fungivores and predators were absent from two samples each. In terms of percentage share in a community, the Eudominant genera were Acrobeles and Boleodorus while the dominant genera were Chronogaster,

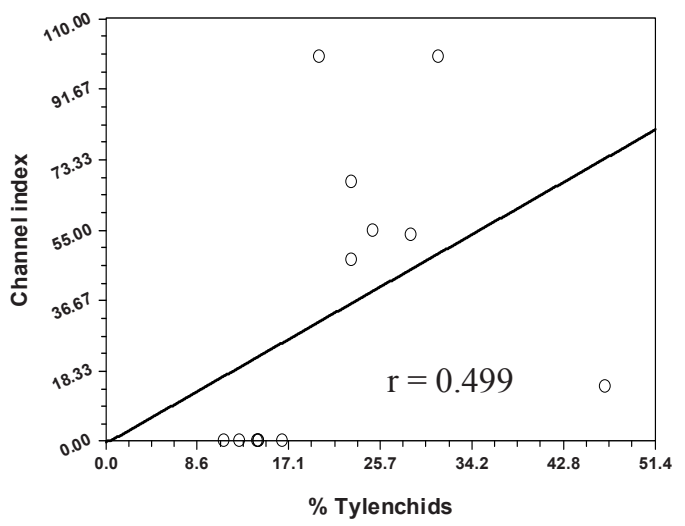


Prismatolaimus and Mesodorylaimus. The genera Alaimus, Cephalobus, Mesorhabditis, Monhystera, Panagrolaimus, Zeldia, Hoplolaimus, Merlinius, Oriverutus, Tylenchus, Aphelenchus, Aphelenchoides, Tylencholaimus, Dorylaimus, Eudorylaimus, Aporcelaimellus, Discolaimus, Dorylaimoides, Ironus, and Tripyla were subdominants while rest were recedents. feeding roles (Gupta \& Yeates, 1997), than for other mesofauna and they can be used in case studies for biomonitoring and ecological investigations. Analysis of the generic composition of nematode community and determination of dominant genus with the application of current knowledge on their biology is an effective tool in evaluating the role of nematodes in the soil processes (Háněl, 1995, 1998).

Table 4. Correlation coefficient between different indices

\begin{tabular}{|c|c|c|c|c|c|c|c|c|c|}
\hline & MI & PPI & NCR & D\% & T\% & O\% & CI & SI & EI \\
\hline MI & 1.000 & & & & & & & & \\
\hline PPI & .024 & 1.000 & & & & & & & \\
\hline NCR & .009 & -.264 & 1.000 & & & & & & \\
\hline D\% & $.725 * *$ & -.199 & -.255 & 1.000 & & & & & \\
\hline T\% & -.422 & $.579 *$ & -.235 & $-.576^{*}$ & 1.000 & & & & \\
\hline O\% & -.227 & -.478 & $.524 *$ & -.321 & $-.589 *$ & 1.000 & & & \\
\hline CI & -.092 & .342 & $-.524 *$ & -.301 & .499 & -.279 & 1.000 & & \\
\hline SI & .305 & -.435 & .387 & .027 & -.280 & .305 & -.300 & 1.000 & \\
\hline EI & -.475 & -.386 & .245 & -.165 & -.133 & .322 & -.439 & .386 & 1.000 \\
\hline
\end{tabular}

Functional diversity and food web diagnostics

For assessing the functional diversity and role of nematodes in the forest ecosystem, various indices were calculated using the weighted faunal analysis concept of Bongers (2001). The results are presented in Table 3.

Correlation studies between population of dorylaims, tylenchids and other nematode groups (Table 4, Fig. 2) with various indices obtained in the present study revealed a high degree of positive or negative correlations. A high degree of positive correlation $(+0.725)(\mathrm{P}<0.01)$ was recorded between population of dorylaims and MI, but for rest all other indices it was either negatively correlated or almost no correlation existed. Population of tylenchids were significantly correlated with PPI $(+0.579)(\mathrm{P}<0.05)$, and to a certain level with CI $(+0.342)$ (ns), while some degree of negative correlation was found with MI (-0.422) (ns). No correlation was found with EI. Population of other nematodes showed a positive correlation to a certain level with SI $(+0.305)$ and EI $(+0.322)$ while it was negatively correlated with PPI (-0.478) (ns). The graph plotted between enrichment index and structure index (faunal profile) was found to be tilted towards quadrat C (Fig.3), giving the idea of relatively undisturbed ecosystem with moderate enrichment and fungal decomposition channels (high values of $\mathrm{CI}$ ).

\section{Discussion}

In recent years, much emphasis has been given to belowground diversity and its relationship with above-ground diversity. In soil, nematodes, collembolans and mites are the three groups of mesofauna which are considered as important biological indicators. Of the three groups, nematodes may be the most suitable for environmental diagnosis based on the community structure analysis, because more information exists on their taxonomy and

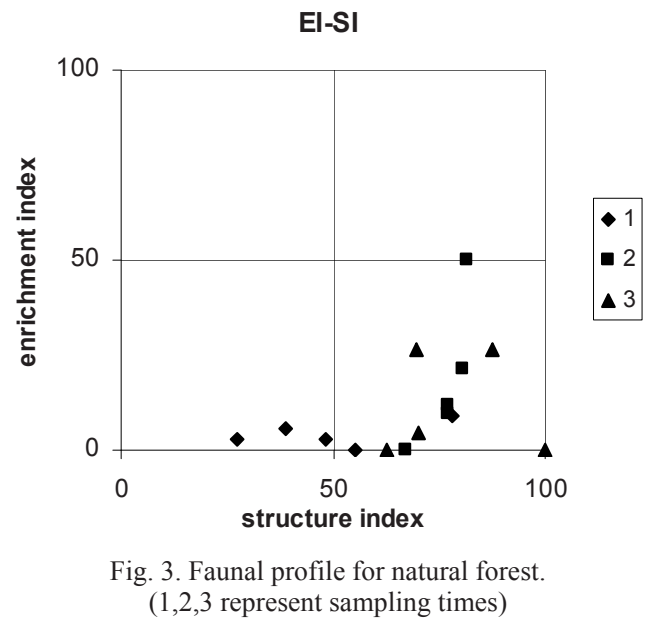

The population fluctuation of herbivores is connected with plant growth in fields while those of bacteriovores with periodic changes of soil water content, and fungivores with fungal root decomposition in the soil. Stress factor as pollution might have a considerable effect on functioning and stability of nematode community because of disappearance of the most sensitive species (cp 4 and cp 5), resulting in decreasing diversity (Korthals et al., 1996). The most sensitive nematode species to pollutants and other disturbances are the predators and omnivores nematodes. The predators regulate other soil biota numerically by feeding at the most dominant prey, which in turn provide an opportunity for recedent species to grow. The omnivores assist predators, bacterivores and fungivores where necessary. As these persistors are the first to disappear, it is likely that system becomes less stable functionally in terms of soil borne plant pathogens and buffering against seasonal and unpredictable nutrient flushes (Bongers \& Bongers, 1998). 
In the present study fifty two nematode genera were recorded with bacteriovores constituting the most dominant group which is in full agreement with Yeates (2003) report of dominance of bacterial feeders in forest soil. The high value of Shanon-Weaver index $\left(\mathrm{H}^{\prime}\right)$ in the present study confirm well with the earlier reports for a pine forest, 1.99 (Yeates, 1998) and 2.62 (Yeates, 2003) respectively, but was lower compared to one recorded for a natural forest in Arunachal Pradesh, India (Baniyamuddin et al., 2007).

They recorded H' value as high as 3.86 , which may be due to the fact that natural forest in that part of India has enormous plant diversity and is probably responsible for much diverse nematode fauna. The high value of MI (3.16) in the present study correspond well with the earlier reports, 2.68 (Háněl, 1996), 2.07 (Pattison et al., 2004) and 3.37 (Baniyamuddin et al., 2007) in the natural forest. TDI also indicated high diversity of trophic groups in this study. Population of dorylaims showed a high degree of positive correlation with $\mathrm{MI}$, as the dorylaims generally represent cp 4 -5 nematodes (the group having long generation time, low fecundity and great sensitivity to disturbance), and their weighted mean results in high value of MI. Population of tylenchids also significantly correlated with PPI, as majority of tylenchids are plant parasites and are responsible for plant parasitic channel in the ecosystem. The value of plant parasitic index showed the presence of parasitic channels in the food web, which are reported to be present in a mature forest ecosystem (Baniyamuddin et. al., 2007). Ecological indices such as CI, SI and EI provide an insight into the nematode community structure in stressed, enriched, stable structured and decomposition environments, and provide information on the dynamics of the soil food web (Ferris et al., 2001). The percentage of the opportunistic nematode grazers on fungi and bacteria, weighted by their fecundity and life course characteristics gives the nature of decomposition channels through soil food web, which is measured as CI. It gives the degree of fungal participation in the primary decomposition channels of soil food webs. A higher CI at any site indicates a higher proportion of fungal decomposition and reflect the high relative abundance of cp2 fungal feeders (Aphelenchoididae and Aphelenchidae) and the corresponding low abundance of cp1 bacterial feeders (Rhabditidae and Panagrolaimidae). Wasilewska (1997) suggested that high values of CI indicates a slow cycling of elements in the ecosystem because the breakdown of dead tissue by bacteria and fungi releases bio-elements at a rate slower than that caused by phytophages. This may also indicate that there is relatively greater mineralization of nutrients via the decomposition pathways than via consumption of primary production by the nematodes. High CI values recorded in this study imply that decomposition in this natural woodland was fungal dominated food web mainly because of relatively high abundance of cp2 fungal feeders. The SI values in the present study were high in agreement with that of high SI values in the natural woodland (Ferris et al., 2001). This is because of high abundance of omnivores and predators (cp3-5), which suggests a food web with more trophic linkages in the ecosystem (Ferris \& Matute, 2003). Higher SI values suggest a complex community structure with more linkages in the food web, greater resilience, and greater buffering of population (Ferris et al., 2001), which potentially provides more biological control to regulate or suppress plant parasitic nematodes (Berkemans et al., 2003). EI reflects the availability of resources to the soil food web and the response of primary decomposers to the resources (Ferris et al., 2004). Generally, the low values of EI reflects low abundance of Rhabditidae and dominance of Cephalobidae which is in full agreement with present findings, as EI values are low because of the dominance of Cephalobidae, and low abundance of Rhabditidae.

The graphical representation of EI and SI is termed as faunal profile, where four quadrats (A, B, C and D) can be recognized for different type of soil conditions. The natural forests have food webs predominantly in quadrat $\mathrm{C}$ of the faunal profile in full agreement with present results (Fig. 3), indicating structured food webs and relatively low primary productivity. Many areas reflect the effect of management or disturbance. Some appear highly disturbed and nutrient enriched so that opportunistic nematode predominate (quadrat A, Ferris et al., 2001), while in some others, the food webs of the managed grasslands have attained some structure while still exhibiting a high level of primary productivity (quadrat B). Other areas may have quadrat $\mathrm{C}$ food web similar to that in natural grasslands.

Nematode faunal analysis provides a powerful tool for diagnosis of the complexity and status of soil food webs (Wardle et al., 1995; Ritz \& Trudgill, 1999) which can also be concluded from present study. The values of indices studied here agree well with earlier reports of these indices from natural forest ecosystems. Accordingly, the present study of the functional diversity and food web diagnostics show natural woodland dominated by Acacia, near Aligarh in India as mature undisturbed ecosystem.

\section{Acknowledgments}

The authors are thankful to the Department of Science and Technology, Government of India for financial assistance and to the Chairman, Department of Zoology, Aligarh Muslim University for providing laboratory facilities.

\section{References}

AhMAD, W. (1996): Plant parasitic nematodes of India: An identification Manual. Aligarh Muslim University, Aligarh, India: Department of Zoology, 347 pp.

ANDrÁssy, I. (1984): Klasse Nematoda (Ordungen Monhysterida, Desmoscolecida, Araeolaimida, Chromadrida, Rhabditida). Gustav Fishcer Verlag. Stuttgart, 509 pp.

Baniyamuddin, Md., Tomar, V. V. S, Ahmad, W. (2007): Functional diversity of soil inhabiting nematodes in natural forests of Arunachal Pradesh, India. Nematol. Mediterr., 35: $109-121$

Berkemans, R., Ferris, H., Tenuta, M., van Bruggn, A. H. C. (2003): Effects of long-term crop management on 
nematode trophic levels other than plant feeders disappear after 1 year of disruptive soil management. Appl. Soil Ecol., 23: 223 - 235

BONGERS, T. (1990): The maturity index: an ecological measure of environmental disturbance based on nematode species composition. Oecologia, 83: $14-19$

BONGERS, T. (1999): The maturity index, the evolution of nematode life history traits, adaptive radiation and cpscaling. Plant Soil, 212: $13-22$

Bongers, T., Bongers, M. (1998): Functional diversity of nematodes. Appl. Soil Ecol., 10: 239 - 251

Bongers, T., Ferris, H. (1999): Nematode Community Structure as a bio-indicator in environmental monitoring. Elsevier Sci. Tree, 14: 224 - 228

Ferris, H., MATUTE, M. M. (2003): Structural and functional succession in the nematode fauna of a soil food web. Appl. Soil Ecol., 23: 93 - 110

Ferris, H., Bongers, T., de Goede, R. G. M. (2001): A framework for soil food web diagnostics: extension of nematode faunal analysis concept. Appl. Soil Ecol., 18: 13 $-29$

Ferris, H., Venette, R. C., Scow, K. M. (2004): Soil management to enhance bacteriovore and fungivore nematode populations and their nitrogen mineralization function. Appl. Soil Ecol., 25: 19 - 35

FreCKMAN, D. W. (1982): Parameter of the nematode contribution to ecosystems. In: FrECKMAN, D. W. (Ed) Nematode in Soil Ecosystems. University of Texas Press, Austin, TX. pp. $81-97$

Gupta, V. V. R., Yeates, G. W. (1997): Soil microfauna as bioindicators of soil health. Pp. $201-234$. In: DouBLE B. M. AND GuPTA V. V. R. (Eds) Biological Indicators of Soil Health. CAB International, Wallingford, UK

HÁNĚL, L. (1995): Secondary successional stages of soil nematodes in cambisols of South Bohemia. Nematologica, 41: 197-218.

HÁNĔL, L. (1996): Comparison of soil nematode communities in three spruce forests at the Boubin Mount, Czech Republic. Biologia Bratislava, 51: 485 - 493

HÁNĔL, L. (1998): Distribution of nematodes in soil, mycorrhizal soil, mycorrhizae and roots of spruce forests at the Boubin Mount, Czech Republic. Biologia Bratislava, 53: 593-603.

Heip, C., Herman, P. M. J., Soetaert, K. (1988): Data processing evaluation and analysis. In: HigGins, R. P., THIEL, H. (Eds) Introduction to the study of Meiofauna. Smithsonian Institution Press, Washington, USA.

JAIRAJPURI, M. S., KHAN, W. U. (1982): Predatory Nematodes (Mononchida) with special reference to India. Associate Pub. Co., New Delhi, 131 pp.

JAIRAJPuri, M. S., AhmAD, W. (1992): Dorylaimida: Free living, Predacious and plant parasitic nematodes. E. J. Brill, Leiden, The Netherlands, 458 pp.

Korthals, G. W., De Goede, R. G. M., Kammenga, J. E., BONGERS, T. (1996): The maturity index as an instrument for risk assessment of soil pollution. In: VAN
Straalen, N. M., Krivolutsky, D. A. (Eds) Bioindicator Systems for Soil Pollution. Kluwer, pp 85 - 93

PAHL-WOSTL, C. (1995): The Dynamic Nature of Ecosystems, Chaos and Order Entwined. Wiley, New York, $267 \mathrm{pp}$.

Peterson, H. (1982): Structure and size of animal populations. Oikos, 39: $306-329$

Pradhan, G. B., Das, M. E. (1987): Distribution and population dynamics of soil nematodes in a tropical forest ecosystem from Sambalpur, India. Indian Acad. Sci. Anim. Sci., 96: $395-402$

Ritz, K., TrudgilL, D. L. (1999): Utility of nematode community analysis as an integrated measure of the functional state of the soils: perspectives and challenges. Plant Soil, 212: $1-11$

RUESS, L. (1995): Studies of nematode fauna on an acid forest soil, spatial distribution and extraction Nematologica, 41: $229-239$

RUESS, L. (2003): Nematode soil faunal analysis of decomposition pathways in different ecosystems. Nematology, 5: $179-189$

ŚÁLY, A. (1975): Study of biomass and caloric value of the soil nematode population in Hornbeam oak wood in Báb. Biologia Bratislava, 30: 615 - 620

SAMOILOFF, M. R. (1987): Nematodes as indicators of toxic environmental contaminants. In: VEECH, J. A. AND Dickson, D. W. (Eds) Vistas on Nematology. E. O. Painter, De Leon prings FL. pp 433 - 439

Shannon, C. E., WeAvers, W. (1949): The mathematical theory of communication. Urbana, IL: University of Illinois.

SIDDIQI, M. R. (1986): Tylenchida: Parasites of Plants and Insects. Farnham Royal, UK: Commonwealth Agriculture Bureaux, pp. 645.

Tomar, V. V. S., Baniyamuddin, Md., Ahmad, W. (2006): Community structure of soil inhabiting nematodes in a mango orchard at Aligarh, India. Int. J. Nematol., 16: $89-101$

Wardle, D. A., Yeates, G. W., Watson, R. N., Nicholson, K.S. (1995): The detritus food web and the diversity of soil fauna as indicators of disturbance regimes in agroecosystems. Plant Soil, 170: 35 - 43

WASILEWSKA, L. (1997): Soil invertebrates as bioindicators, with special reference to soil inhabiting nematodes. Russ. J. Nematol., 5: $133-126$

YeAtes, G. W. (1972): Nematode of the Danish beach forest, I. Methods and general analysis. Oikos, 23: $178-$ 189

YeAtes, G. W. (2003): Nematodes as soil indicators: Functional and Biodiversity aspects. Biol. Fertil. Soils, 37 : $199-210$

Yeates G. W., Bongers T., de Goede R. G. M., FreckMan D. W., Georgieva S. S. (1993): Feeding habits in soil nematode families and genera - an outline for soil ecologists. J. Nematol., 25: $315-331$ 